\title{
Airway inflammation following exposure to diesel exhaust: a study of time kinetics using induced sputum
}

\author{
C. Nordenhäll*, J. Pourazar*, A. Blomberg*, J-O. Levin**, T. Sandström*, E. Ädelroth*
}

\begin{abstract}
Airway inflammation following exposure to diesel exhaust: a study of time kinetics using induced sputum. C. Nordenhäll, J. Pourazar, A. Blomberg, J-O. Levin, T. Sandström, E. Ädelroth. (C) ERS Journals Ltd 2000.

ABSTRACT: The adverse health effects of particulate matter pollution are of increasing concern. In a recent bronchoscopic study in healthy volunteers, pronounced airway inflammation was detected following exposure to diesel exhaust (DE). The present study was conducted in order to evaluate the time kinetics of the inflammatory response following exposure to $\mathrm{DE}$ using induced sputum from healthy volunteers.

Fifteen healthy nonsmoking volunteers were exposed to DE particles with a 50\% cut-off aerodynamic diameter of $10 \mu \mathrm{m} \mathrm{300} \mu \mathrm{g} \cdot \mathrm{m}^{-3}$ and air for $1 \mathrm{~h}$ on two separate occasions. Sputum induction with hypertonic saline was performed 6 and $24 \mathrm{~h}$ after each exposure. Analyses of sputum differential cell counts and soluble protein concentrations were performed.

Six hours after exposure to DE, a significant increase was found in the percentage of sputum neutrophils $(37.7$ versus $26.2 \% \mathrm{p}=0.002)$ together with increases in the concentrations of interleukin-6 (12.0 versus $\left.6.3 \mathrm{pg} \cdot \mathrm{mL}^{-1}, \mathrm{p}=0.006\right)$ and methylhistamine (0.11 versus $\left.0.12 \mu \mathrm{g} \cdot \mathrm{L}^{-1}, \mathrm{p}=\mathbf{0 . 0 2 4}\right)$. Irrespective of exposure, a significant increase was found in the percentage of sputum neutrophils at 24 as compared to $6 \mathrm{~h}$, indicating that the procedure of sputum induction itself may change the composition of sputum.

This study demonstrates that exposure to diesel exhaust induces inflammatory response in healthy human airways, represented by an early increase in interleukin -6 and methylhistamine concentration and the percentage of neutrophils. Induced sputum provides a safe tool for the investigation of the inflammatory effects of diesel exhaust, but care must be taken when interpreting results from repeated sputum inductions.

Eur Respir J 2000; 15: 1046-1051.
\end{abstract}

\author{
*Dept of Respiratory Medicine and \\ Allergy, University Hospital, and **Dept \\ of Occupational Chemistry, Institute for \\ Working Life, Umeå Sweden.
}

Correspondence: E. Ädelroth

Dept of Respiratory Medicine and Allergy University Hospital

S-90185 Umeå

Sweden

Fax: 4690141369

Keywords: Airway inflammation

diesel exhaust

induced sputum

neutrophils

Received: April 211999

Accepted after revision December 61999

This study was supported by the Swedish Heart and Lung Foundation.
The adverse health effects of particulate matter (PM) pollution are of increasing concern as several epidemiological studies have revealed an association between elevations in ground level PM concentrations and increased morbidity and mortality from cardiovascular and respiratory causes [1-7].

Recently, attention has been directed towards the particulate air pollution emitted from diesel engines. The number of diesel-powered cars is rising and diesel engines emit up to 100 times more particles than petrol engines $[8,9]$. Diesel exhaust (DE) particles contain a carbonaceous core, which adsorbs various metals and organic compounds on its surface. Consequently, the biological effects of DE may be explained by not only the gases and pure particles but also by these surface components.

The number of studies investigating the effects of $\mathrm{DE}$ has increased during recent years. In working environments, exposure to $\mathrm{DE}$ has been associated with various symptoms related to the eyes and airways [10-12]. In experimental chamber studies, DE has been shown to cause airway symptoms [13] and to induce an acute inflammatory response in human airways as reflected in bronchoalveolar lavage [14, 15] and bronchial biopsy
[16] samples. Further, local nasal challenge with DE particles has been reported to enhance immunoglobulin $\mathrm{E}$ production in the nose [17] and to cause an increased cytokine response in the nose of allergic subjects [18].

The concentration of PM used in this study is comparable to high ambient levels in large European cities. From a global perspective, more than half of the world's megacities (cities with population $>10$ million) have annual mean PM concentrations ranging $200-600 \mu \mathrm{g} \cdot \mathrm{m}^{-3}$ [7]. In addition, high concentrations of $\mathrm{DE}$ are found in various working environments such as mines, garages and other enclosed spaces containing running engines.

Fibreoptic bronchoscopy has become a central tool for the examination of air pollution effects in human airways. Bronchoscopy is an invasive and resource-demanding method and cannot be easily performed repeatedly in the same subject within a limited period of time. Thus there has been an increasing demand for a noninvasive and alternative method to be used in situations in which bronchoscopy is not practical. Sputum induction has been proposed as a safe, noninvasive and easily repeated method for monitoring inflammatory events in human airways, and the method of sputum induction has been validated in a number of 
studies and reported to be safe and reproducible [19-23]. Analysis of induced sputum results has shown them to correlate well with data obtained from bronchial wash and bronchoalveolar lavage [24, 25]. In air pollution research, induced sputum has previously proved valuable in the evaluation of the airway effects of ozone [26] and nitrogen dioxide [27].

This study was conducted in order to elucidate the time kinetics of the inflammatory response following short-term exposure to DE in healthy human volunteers. In addition, the use of induced sputum as a noninvasive tool for the investigation of the inflammatory effects of DE was evaluated.

\section{Methods}

\section{Subjects}

The study population comprised fifteen healthy nonsmoking volunteers (two females and 13 males; mean age 25 yrs, range 22-33 yrs), with lung function within the normal range. None of the subjects had a history of allergy, asthma or any other pulmonary disease and none had experienced any respiratory tract infection for $\geq 4$ weeks prior to or during the study period. As a part of the screening procedure for participation in the study, all subjects were tested as to their ability to produce sputum on induction with hypertonic saline. The study was approved by the local Ethics Committee of Umeå University and verbal and written informed consent was obtained from all individuals.

\section{Study design}

The study was performed using a single-blind crossover design with each subject acting as their own control. Each subject was exposed for $1 \mathrm{~h}$ on two different occasions, once to filtered air and once to DE at a concentration of particles with a $50 \%$ cut-off aerodynamic diameter of 10 $\mu \mathrm{m}$ (PM10) of $300 \mu \mathrm{g} \cdot \mathrm{m}^{-3}$. In order to preclude any bias due to possible carry over effects, the exposures were conducted $\geq 2$ weeks apart and in randomized sequence, with half of the study population being exposed to DE as their first exposure and the other half being exposed to air first.

\section{Exposure}

During each exposure, the subjects alternated between rest and moderate exercise on a bicycle ergometer (minute ventilation per square metre of body surface area $20 \mathrm{~L}$. $\mathrm{min}^{-1} \cdot \mathrm{m}^{-2}$ ) at 15 -min intervals. All exposures were performed in an environmental chamber according to a previously described standard protocol $[16,28]$. This exposure system has been carefully evaluated and validated [28]. DE was generated by an idling Volvo diesel engine (Volvo-BM TD45; Volvo, Gothenburg, Sweden; 4.5 L, 4 cylinders, 1991, 680 revolutions per minute (rpm)). Approximately $90 \%$ of the exhaust was shunted away and the remaining part diluted with air and fed into the chamber at a steady-state concentration. The concentrations of particles (particles $\cdot \mathrm{cm}^{-3}$ ), $\mathrm{NO}_{2}$, nitric oxide, carbon monoxide and hydrocarbons ( $\mathrm{HCs}$ ) were continuously record- ed in the exposure chamber as previously described [13]. A gas analyser using infrared detection (Miran 1-A; Foxboro Co, East Bridgewater, MA, USA) was used for analysis of $\mathrm{CO}$. $\mathrm{NO}, \mathrm{NO}_{2}$ and oxides of nitrogen $\left(\mathrm{NO}_{\mathrm{x}}\right)$ were measured using an $\mathrm{NO}_{\mathrm{x}}$ analyser with chemiluminescence detection (ECO-Physics CLD 700; Boo-Instruments, Stockholm, Sweden). HCs were measured using a hydrogen analyser with a flame ionization detector (model 3-300; (J.U.M. Engineering GmbH; Munich, Germany) with a heated prefilter $\left(180^{\circ} \mathrm{C}\right)$ and calibrated with propane. The mass of the PM10 (in $\mu \mathrm{g} \cdot \mathrm{m}^{-3}$ ) was determined by weighing PM10-collecting filters. The air in the chamber was changed every $2-3 \mathrm{~min}$, with the waste air being extracted through a tube in the ceiling. The DE entering the environmental chamber was standardized to give a PM10 concentration of $300 \mu \mathrm{g} \cdot \mathrm{m}^{-3}$, associated with a median steady-state $\mathrm{NO}_{2}$ concentration of 1.6 parts per million. The temperature and relative humidity in the chamber were kept at $20^{\circ} \mathrm{C}$ and $50 \%$ respectively.

\section{Sputum induction}

Sputum induction was performed 6 and $24 \mathrm{~h}$ after each exposure. The induction procedure was performed according to the method described by PIN et al. [23]. All subjects were pretreated with an inhaled $\beta_{2}$-agonist $(0.5 \mathrm{mg}$ terbutaline). Hypertonic saline was nebulized using an ultrasonic nebulizer (DeVilbiss 2000; DeVilbiss Co., Somerset, PA, USA), with an output of $1.5 \mathrm{~mL} \cdot \mathrm{min}^{-1}$. Inhalation was performed at intervals of $7 \mathrm{~min}$ with increasing concentrations $(3,4$ and $5 \%)$ of saline solution. The forced expiratory volume in one second was monitored before and after every inhalation period. All subjects received all three concentrations of saline. Following each inhalation interval, subjects were advised to rinse their mouth with water and blow their nose before trying to cough sputum into a sterile plastic container. The samples obtained were kept on ice up to $1 \mathrm{~h}$ prior to processing.

\section{Sputum processing}

Sputum was processed according to the method described by Pizzichini et al. [19]. The expectorated samples were poured into a siliconized Petri dish and macroscopically examined, and portions that appeared more viscid and dense were selected with forceps and transferred to a 10$\mathrm{mL}$ siliconized tube. After adding $0.1 \%$ diothiothreitol (DTT) at a volume equal to four times the selected sputum weight, the sputum was rocked for $15 \mathrm{~min}$ to dissolve the mucus and disperse the cells. The same volume of phosphate-buffered saline $0.01 \mathrm{M}, \mathrm{pH} 6.9$ (PBS) was added and the rocking continued for $5 \mathrm{~min}$. The mixture was then filtered through a $48-\mu \mathrm{m}$ nylon filter into another $10-\mathrm{mL}$ tube and centrifuged for $10 \mathrm{~min}$ at $300 \times g$ at $4{ }^{\circ} \mathrm{C}$. The supernatant was separated from the cell pellet, recentrifuged for $10 \mathrm{~min}$ at $1,000 \times g$ to further remove debris, aspirated and stored in Eppendorf tubes at $-70^{\circ} \mathrm{C}$ for later analyses. The cell pellet was resuspended in $1,000 \mu \mathrm{L}$ PBS. Total cell counts and cell viability were determined using a haemocytometer and trypan blue. The cell suspension was adjusted to $0 \cdot 5 \times 10^{6} \mathrm{cells} \cdot \mathrm{mL}^{-1}$ and $50 \mu \mathrm{L}$ placed in each cup of a Shandon 3 cytocentrifuge (Shandon Southern Instruments, Inc., Sewickley, PA, USA) and cytospins made on prewet slides. Six cytospin 
slides per sputum sample were prepared (400 rpm, $5 \mathrm{~min}$ ) and stained with May-Grünwald Giemsa. At least 400 nonsquamous cells were counted by two blinded observers and the results were averaged to yield the final differential cell counts reported. The differential cell counts were expressed as a percentage of the total nonsquamous cell count. The proportion of squamous cells was obtained by counting 400 additional cells and expressed as a percentage of the total cell count. Samples were considered suitable for analysis if squamous cell contamination was $<20 \%$ and viability $>50 \%$. The total cell count is expressed as the number of cells per millilitre of the undiluted sputum on the assumption that $1 \mathrm{~g}$ of sputum is equivalent to $1 \mathrm{~mL}$.

\section{Fluid phase mediators}

The levels of seven different soluble proteins in the sputum supernatant samples were determined. Methylhistamine (M-hist), eosinophil cationic protein (ECP) and myeloperoxidase (MPO) concentrations were determined using sensitive commercial radioimmunoassay kits (Pharmacia \& Upjohn AB, Uppsala, Sweden). Tumour necrosis factor- $\alpha$ (TNF- $\alpha$ ), interleukin (IL)-6, IL-8 and growthrelated oncogene- $\alpha$ (Gro- $\alpha$ ) levels were measured using commercial enzyme-linked immunosorbent assay kits (R\&D systems, Inc., Abingdon, UK). The concentrations presented have not been corrected for sputum dilution. All fluid-phase measurements were performed blind to the subject's exposure history.

\section{Statistics}

The Wilcoxon nonparametric signed-rank test for paired observations was used to compare data on cells and soluble markers after air and diesel exhaust exposures. Correlations between data were assessed using the Spearman rank correlation test. The primary end point was defined as a change in the percentage of neutrophils in induced sputum following exposure to diesel exhaust. A p-value of $<0.05$ was considered significant.

\section{Results}

Sputum induction was well tolerated by all subjects. The median (interquartile range) salivary contamination indicated by the percentage of squamous cells was 3.7\% (1.6$9.0 \%)$ and the median cell viability was $76 \%$ (67-84\%). The median weight of the selected sputum was $300 \mathrm{mg}$ $(158-410 \mathrm{mg})$. Only one sputum sample was discarded from the study due to insufficient volume.

\section{Sputum cell counts}

The results of the sputum differential cell count analysis are presented in table 1. Exposure to DE induced an increase in the percentage of neutrophils at $6 \mathrm{~h}(\mathrm{p}=0.002)$ but not at $24 \mathrm{~h}$, compared with the equivalent time points following air exposure (fig. 1). The median increase seen at $6 \mathrm{~h}$ was $49.8 \%$. At $24 \mathrm{~h}$ after exposure, a minimal but significant increase $(\mathrm{p}=0.046)$ was found in the percentage of lymphocytes, whereas no change was seen at the earlier time point. No significant change was seen in the percentage of ciliated epithelial cells or squamous cells or total cell counts. Only very few samples contained eosinophils.

Irrespective of exposure, sputum induced at $6 \mathrm{~h}$ contained significantly lower percentages of neutrophils compared with sputum from the subsequent induction at $24 \mathrm{~h}$. Correspondingly, the percentages of macrophages were higher at $6 \mathrm{~h}$ than at $24 \mathrm{~h}$ after exposure. The percentages of ciliated epithelial cells and lymphocytes were significantly lower at $24 \mathrm{~h}$ compared with $6 \mathrm{~h}$ following air exposure but not following diesel exposure.

\section{Fluid phase mediators}

Six hours after diesel exposure, a significant increase was seen in the fluid phase concentrations of IL-6 and Mhist compared with after exposure to air, whereas no significant changes were detected in the levels of ECP, Gro- $\alpha$, IL-8, MPO or TNF- $\alpha$. At $24 \mathrm{~h}$ after exposure, no significant changes were seen in the soluble protein concentrations (table 2).

Table 1. - Total and differential cell counts in sputum after air and diesel exposure

\begin{tabular}{|c|c|c|c|}
\hline & Air & Diesel & p-value \\
\hline \multicolumn{4}{|c|}{ Total cell count $10^{6}$ cells $\cdot \mathrm{mL}^{-1}$} \\
\hline $6 \mathrm{~h}$ & $2.25(1.30-2.78)$ & $2.00(0.56-3.10)$ & NS \\
\hline $24 \mathrm{~h}$ & $1.90(0.95-2.70)^{+}$ & $1.07(0.36-2.70)$ & NS \\
\hline \multicolumn{4}{|c|}{ Neutrophils \% } \\
\hline $6 \mathrm{~h}$ & $26.2(13.5-37.9)$ & $37.7(22.2-46.3)$ & 0.002 \\
\hline $24 \mathrm{~h}$ & $60.0\left(55.6-65.25^{* *},+\right.$ & $61.9(45.9-76.9) *$ & NS \\
\hline \multicolumn{4}{|c|}{ Macrophages \% } \\
\hline $6 \mathrm{~h}$ & $72.0(60.0-74.0)$ & $57.2(40.4-72.1)$ & 0.027 \\
\hline $24 \mathrm{~h}$ & $37.8(32.1-47.5)^{* *,+}$ & $37.3\left(21.5-53.0^{*}\right.$ & NS \\
\hline \multicolumn{4}{|c|}{ Lymphocytes \% } \\
\hline $6 \mathrm{~h}$ & $0.70(0.55-1.10)$ & $0.6(0.35-1.20)$ & NS \\
\hline $24 \mathrm{~h}$ & $0.47(0.20-0.65)^{*,+}$ & $0.65(0.40-0.80)$ & 0.046 \\
\hline \multicolumn{4}{|c|}{ Ciliated epithelial cells\% } \\
\hline $6 \mathrm{~h}$ & $2.40(0.70-10.8)$ & $2.75(0.70-4.20)$ & NS \\
\hline $24 \mathrm{~h}$ & $1.15(0.71-2.35)^{+}$ & $1.00(0.30-2.15) \S$ & NS \\
\hline
\end{tabular}

Data are presented as median (interquartile range) $(n=15)$. The total cell count is expressed as the number of cells per millilitre of the undiluted sputum on the assumption that $1 \mathrm{~g}$ of sputum is equivalent to $1 \mathrm{ml} .{ }^{+}: \mathrm{n}=14{ }^{\#}{ }^{\#}$ : Wilcoxon nonparametric signed-rank test. ${ }^{\S}$ : $\mathrm{p}=0.10 ; *$ : $\mathrm{p}<0.05 ; * * \mathrm{p}<0.01$ versus $6 \mathrm{~h}$. 


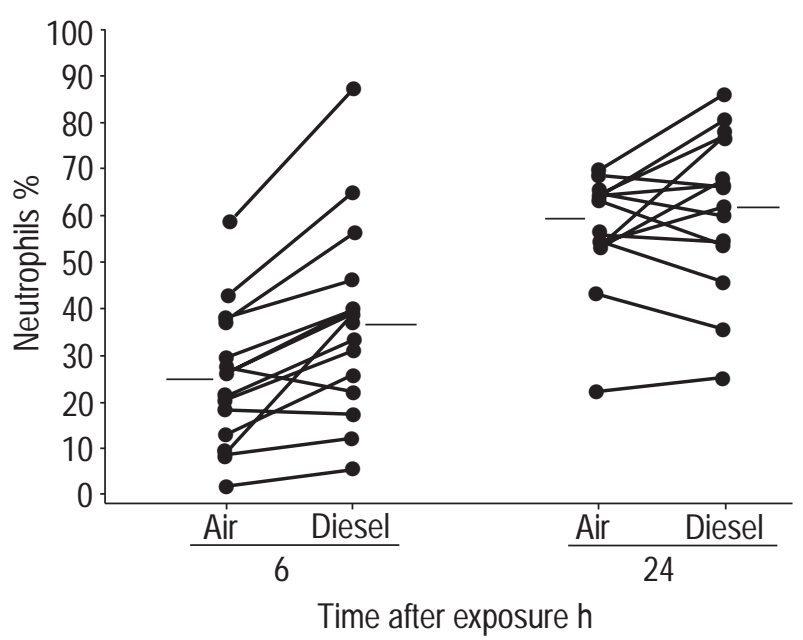

Fig. 1. - Percentages of neutrophils in induced sputum from healthy subjects at $6(n=15)$ and $24 \mathrm{~h}(\mathrm{n}=14)$ after exposure to air and diesel exhaust. The horizontal bars represent medians.

When comparing the levels of soluble proteins in sputum from the induction at $6 \mathrm{~h}$ with those from the subsequent induction at $24 \mathrm{~h}$, there was a significant increase in ECP concentration at $24 \mathrm{~h}$ after air exposure. No other significant changes were seen in soluble protein concentrations from the two consecutive sputum inductions (table 2).

\section{Discussion}

Cellular and biochemical analysis of induced sputum revealed an inflammatory response in the airways following exposure to $\mathrm{DE}$ as compared to air. Inflammatory changes were found in differential cell counts as well as in fluid phase mediator concentrations. The inflammatory response to DE is likely to involve a sequence of events, with various cellular and protein effects suggested to appear at different time points following exposure. The levels of certain inflammatory substances are thus likely to depend on the time of sampling. In the present study, the time course of the inflammatory process following DE exposure was addressed by comparing levels of soluble proteins and cellular changes in sputum observed at $6 \mathrm{~h}$ after exposure to DE with those observed at $24 \mathrm{~h}$.

The early increases in IL-6 and M-hist concentration probably represent an acute and transient response to $\mathrm{DE}$ and may result from direct effects of DE on airway cells. IL-6 is a pro-inflammatory cytokine that displays a diversity of functions, including regulation of immunological responses and induction of acute-phase reactions [29]. An increase in the release of IL-6 from human bronchial epithelial cells has recently been reported following in vitro exposure to $\mathrm{DE}$ particles [30], as well as to particles derived from residual oil fly ash [31]. Furthermore, air pollution particulates have been shown to induce IL-6 gene expression in bronchial epithelial cells via nuclear factor- $\kappa \mathrm{B}$ activation [32]. Combined, these data suggest that epithelial cells, being the first cellular target of inhaled air pollutants, may release IL-6 upon exposure to DE. The early increase in M-hist most probably represents mast cell degranulation in the airway mucosa as indicated in a preceding bronchoscopic study [16].

The early neutrophilic response in sputum differential cell counts observed in the present study corresponds well with the previous data, in which an increase in neutrophil number was found in both bronchial biopsy and bronchial wash samples at $6 \mathrm{~h}$ after DE exposure [16]. The presence of a neutrophilic inflammation has further been reported in BAL at $18 \mathrm{~h}$ after DE exposure $[14,15]$. Although the human data on the time course of the neutrophilic response to DE is limited, the results from these studies seem to suggest the peak response to occur sometime between 6 and $18 \mathrm{~h}$ following exposure.

Table 2. - Levels of soluble proteins in sputum after air and diesel exposure

\begin{tabular}{|c|c|c|c|c|}
\hline & Subjects $\mathrm{n}$ & Air & Diesel & p-value ${ }^{+}$ \\
\hline \multicolumn{5}{|c|}{$\mathrm{ECP} \mu \mathrm{g} \cdot \mathrm{L}^{-1}$} \\
\hline $6 \mathrm{~h}$ & 15 & $9.2(4.8-25.9)$ & $15.1(7.0-23.4)$ & NS \\
\hline $24 \mathrm{~h}$ & 14 & $28.0(11.4-40.2)^{*}$ & $18.0(5.0-45.8)$ & NS \\
\hline \multicolumn{5}{|c|}{ GRO- $\alpha \mathrm{pg} \cdot \mathrm{mL}^{-1}$} \\
\hline $6 \mathrm{~h}$ & 15 & $552(270-1050)$ & $840(252-1560)$ & NS \\
\hline $24 \mathrm{~h}$ & 13 & $1020(372-1500)$ & $567(321-795)$ & NS \\
\hline \multicolumn{5}{|c|}{$\mathrm{IL}-6 \mathrm{pg} \cdot \mathrm{mL}^{-1}$} \\
\hline $6 \mathrm{~h}$ & 15 & $6.3(4.5-14.4)$ & $12.0(6.9-22.2)$ & 0.006 \\
\hline $24 \mathrm{~h}$ & 14 & $10.4(5.6-19.2)$ & $15.0(10.8-40.8)$ & 0.09 \\
\hline \multicolumn{5}{|c|}{ IL- $8 \mathrm{pg} \cdot \mathrm{mL}^{-1}$} \\
\hline $6 \mathrm{~h}$ & 15 & $990(690-1650)$ & $1290(690-2550)$ & NS \\
\hline $24 \mathrm{~h}$ & 13 & $1800(1065-3188)$ & $1560(660-4200)$ & NS \\
\hline \multicolumn{5}{|c|}{ M-hist $\mu \mathrm{g} \cdot \mathrm{L}^{-1}$} \\
\hline $6 \mathrm{~h}$ & 13 & $0.11(0.00-0.14)$ & $0.12(0.05-0.18)$ & 0.024 \\
\hline $24 \mathrm{~h}$ & 13 & $0.11(0.00-15.5)$ & $0.13(0.11-0.14)$ & NS \\
\hline \multicolumn{5}{|c|}{ MPO $\mu \mathrm{g} \cdot \mathrm{L}^{-1}$} \\
\hline $6 \mathrm{~h}$ & 15 & $162(122-274)$ & $252(152-301)$ & NS \\
\hline $24 \mathrm{~h}$ & 13 & $393(172-543)$ & $246(152-1033)$ & NS \\
\hline \multicolumn{5}{|c|}{ TNF- $\alpha \mathrm{pg} \cdot \mathrm{mL}^{-1}$} \\
\hline $6 \mathrm{~h}$ & 15 & $0.00(0.00-2.55)$ & $1.50(0.00-3.00)$ & NS \\
\hline $24 \mathrm{~h}$ & 14 & $0.00(0.00-3.19)$ & $0.00(0.00-3.19)$ & NS \\
\hline
\end{tabular}

Data are expressed as median (interquartile range). ${ }^{+}$: Wilcoxon nonparametric signed-rank test. ECP: eosinophil cationic protein; Gro$\alpha$ : growth-related oncogene- $\alpha$; IL: interleukin; M-hist: methylhistamine; MPO: myeloperoxidase; TNF- $\alpha$ : tumour necrosis factor- $\alpha$. *: $\mathrm{p}<0.05$ versus $6 \mathrm{~h}$. 
In spite of the increase in sputum neutrophil numbers, no significant change was seen in the fluid phase levels of IL-8 or Gro- $\alpha$. Accordingly, SALvi et al. [16] did not find any increase in IL-8 levels in bronchial lavage fluid at $6 \mathrm{~h}$ after exposure to DE. These findings do not exclude an early transient increase in the levels of IL- 8 and Gro- $\alpha$. Six hours after exposure may be too late to detect any early change that might have occurred. As a marker for neutrophil activation, MPO levels were measured in the sputum supernatant, but no significant change was detected.

Exposure to DE was also associated with higher percentages of lymphocytes detected at $24 \mathrm{~h}$, as compared to the equivalent time point following air. However, this change was small and only weakly statistically significant and should be regarded with caution. Nevertheless in support of the observation in this study, exposure to DE has recently been shown to cause lymphocytosis in bronchoalveolar lavage fluid and bronchial biopsy samples at $6 \mathrm{~h}$ after exposure [16].

The results from the present study indicate that the procedure of sputum induction may itself cause an inflammatory change in the composition of sputum. This is suggested by the significant changes in the cellular and biochemical components found between sputum obtained at 6 compared with sputum obtained at $24 \mathrm{~h}$. Irrespective of exposure, there was a pronounced increase in the percentage of neutrophils at 24 compared with $6 \mathrm{~h}$. Also, sputum induced at $24 \mathrm{~h}$ following air contained higher levels of ECP, compared with sputum induced at $6 \mathrm{~h}$. Differences were further seen in the median percentage of ciliated epithelial cells between sputum obtained at 6 and $24 \mathrm{~h}$, which is most probably explained by shedding of the ciliated epithelial cells during the first induction, thus resulting in lower percentages during the second induction.

Few studies have been conducted to compare sputum results between two consecutive inductions. In accordance with the present results, HoLz et al. [33] recently reported a marked increase in the percentages of neutrophils and ECP levels in induced sputum $24 \mathrm{~h}$ after a previous sputum induction. Similar results were shown by NigHTINGALE et al. [34]. In contrast, other studies have not revealed any significant change in sputum composition following sputum induction performed on consecutive days $[35,36]$. The discrepancy seen between different studies most probably reflects methodological differences and different study populations, but further studies are needed to resolve this issue. Also, most studies using induced sputum have been performed in asthmatics, whereas the available data related to healthy subjects is more limited. In view of the results of the present study, it is suggested that possible inflammatory effects of the induction procedure should be taken into consideration when performing repeated inductions. However this issue might be of less importance if subjects are used as their own controls, as in the present study.

In conclusion, the results of the present study indicate that short-term exposure to diesel exhaust induces a timedependent inflammatory response in the airways of healthy human subjects, involving an early increase in interleukin6 and methylhistamine levels and neutrophil percentages possibly followed by a late increase in the percentage of lymphocytes. Sputum induction is a valuable and easily applicable method for the investigation of airway inflam- mation following exposure to diesel exhaust, but caution must be exercised as to the interpretation of results from repeated sputum inductions.

Acknowledgements. The authors acknowledge the valuable technical assistance of $\mathrm{H}$. Bertilsson, L. Skedebrant, M-C. Ledin and A-B. Lundström.

\section{References}

1. Ostro B. The association of air pollution and mortality: examining the case for inference. Arch Environ Health 1993; 48: 336-342.

2. Dockery DW, Pope CA III, Xu X, et al. An association between air pollution and mortality in six U.S cities. $N$ Engl J Med 1993; 329: 1753-1759.

3. Pope CA III, Bates DV, Raizenne ME. Health effects of particulate air pollution: time for reassessment? Environ Health Perspect 1995; 103: 472-480.

4. Schwartz J. Air pollution and daily mortality in Birmingham, Alabama. Am J Epidemiol 1993; 137: 1136-1147.

5. Schwartz J, Dockery DW. Particulate air pollution and daily mortality in Steubenville, Ohio. Am J Epidemiol 1992; 135: 12-19.

6. Clench-Aas J, Krzyzanovski M. Quantification of health effects related to $\mathrm{SO}_{2}, \mathrm{NO}_{2}, \mathrm{O}_{3}$ and particulate matter exposure. Kjeller, Norwegian Institute for Air Research, 1996.

7. Anonymous. Air pollution of the world's megacities. A report from the UN Environment Program and WHO. Environment 1994; 36: 5-37.

8. Vistal JJ. Health effects of diesel exhaust particulate emissions. Bull N Y Acad Med 1980; 56: 914-934.

9. Quality of Urban Air Review Group. Sources and emissions of primary particulate matter. Airborne particulate matter in the United Kingdom. Third Report. Department of Environment, 1996; pp. 37-55.

10. Ulfvarson U, Alexandersson R, Dahlqvist M, Ekholm U, Bergström B. Pulmonary function in workers exposed to diesel exhausts: the effect of control measures. Am J Ind Med 1991; 19: 283-289.

11. Reger R, Hancock J, Hankinson J, Hearl F, Merchant J. Coal miners exposed to diesel exhaust emissions. Ann Occup Hyg 1982; 26: 799-815.

12. Gamble J, Jones W, Minshall S. Epidemiological-environmental study of diesel bus garage workers: acute effects of $\mathrm{NO}_{2}$ and respirable particulate on the respiratory system. Environ Res 1987; 42: 201-214.

13. Rudell B, Ledin M-C, Stjernberg N, Lundbäck B, Sandström T. Effects on symptoms and lung function in humans experimentally exposed to diesel exhaust. Occup Environ Med 1996; 53: 658-662.

14. Rudell B, Sandström T, Stjernberg N, Kolmodin-Hedman B. Controlled diesel exhaust exposure in an exposure chamber: pulmonary effects investigated with bronchoalveolar lavage. J Aerosol Sci 1990; 21: 411-414.

15. Rudell B, Blomberg A, Ledin M-C, et al. Bronchoalveolar inflammation following exposure to diluted diesel exhaust - comparison between unfiltered and particle trap filtered exhaust. Occup Environ Med 1999; 156: 527534.

16. Salvi S, Blomberg A, Rudell B, et al. Acute inflammatory responses in the airways and peripheral blood following short term exposure to diesel exhaust in healthy human 
volunteers. Am J Respir Crit Care Med 1999; 159: 702709.

17. Diaz Sanchez D, Dotson AR, Takenaka H, Saxon A. Diesel exhaust particles induce local IgE production in vivo and alter the pattern of IgE messenger RNA isoforms. J Clin Invest 1994; 94: 1417-1425.

18. Diaz Sanchez D. The role of diesel exhaust particles and their associated polyaromatic hydrocarbons in the induction of allergic airway disease. Allergy 1997; 52: 52-56.

19. Pizzichini E, Pizzichini MM, Efthimiadis A, et al. Indices of airway inflammation in induced sputum: reproducibility and validity of cell and fluid-phase measurements. Am J Respir Crit Care Med 1996; 154: 308-317.

20. Pizzichini MM, Popov TA, Efthimiadis A, et al. Spontaneous and induced sputum to measure indices of airway inflammation in asthma. Am J Respir Crit Care Med 1996; 154: 866-869.

21. Pavord ID, Pizzichini MM, Pizzichini E, Hargreave FE. The use of induced sputum to investigate airway inflammation. Thorax 1997; 52: 498-501.

22. Fahy JV, Liu J, Wong H, Boushey HA. Cellular and biochemical analysis of induced sputum from asthmatic and from healthy subjects. Am Rev Respir Dis 1993; 147: 1126-1131.

23. Pin I, Gibson PG, Kolendowicz R, et al. Use of induced sputum cell counts to investigate airway inflammation in asthma. Thorax 1992; 47: 25-29.

24. Fahy JV, Wong H, Liu J, Boushey HA. Comparison of samples collected by sputum induction and bronchoscopy from asthmatic and healthy subjects. Am J Respir Crit Care Med 1995; 152: 53-58.

25. Grootendorst DC, Sont JK, Willems LN, et al. Comparison of inflammatory cell counts in asthma: induced sputum $v s$ bronchoalveolar lavage and bronchial biopsies. Clin Exp Allergy 1997; 27: 769-779.

26. Fahy JV, Wong HH, Liu JT, Boushey HA. Analysis of induced sputum after air and ozone exposures in healthy subjects. Environ Res 1995; 70: 77-83.
27. Vagaggini B, Paggiaro PL, Giannini D, et al. Effect of short-term $\mathrm{NO}_{2}$ exposure on induced sputum in normal, asthmatic and COPD subjects. Eur Respir $J$ 1996; 9: 1852-1857.

28. Rudell B, Sandström T, Hammarström U, Ledin ML, Horstedt P, Stjernberg N. Evaluation of an exposure setup for studying effects of diesel exhaust in humans. Int Arch Occup Environ Health 1994; 66: 77-83.

29. Kishimoto T, Akira S, Taga T. Interleukin-6 and its receptor: a paradigm for cytokines. Science 1992; 258: 593597.

30. Steerenberg PA, Zonnenberg JA, Dormans JA, et al. Diesel exhaust particles induced release of interleukin 6 and 8 by (primed) human bronchial epithelial cells (BEAS 2B) in vitro. Exp Lung Res 1998; 24: 85-100.

31. Carter JD, Ghio AJ, Samet JM, Devlin RB. Cytokine production by human airway epithelial cells after exposure to an air pollution particle is metal-dependent. Toxicol Appl Pharmacol 1997; 146: 180-188.

32. Quay JL, Reed W, Samet J, Devlin RB. Air pollution particles induce IL-6 gene expression in human airway epithelial cells via NF-kappaB activation. Am J Respir Cell Mol Biol 1998; 19: 98-106.

33. Holz O, Richter K, Jorres RA, Speckin P, Mucke M, Magnussen $\mathrm{H}$. Changes in sputum composition between two inductions. 1998; 53: 83-86.

34. Nightingale JA, Rogers DF, Barnes PJ. Effect of repeated sputum induction on cell counts in normal volunteers. Thorax 1998; 53: 87-90.

35. Fahy JV, Liu J, Wong H, Boushey HA. Analysis of cellular and biochemical constituents of induced sputum after allergen challenge: a method for studying allergic airway inflammation. J Allergy Clin Immunol 1994; 93: 1031-1039.

36. Floreani AA, Rennard SI, Heires A, Buchalter SE, Thompson $\mathrm{AB}$. Induction of sputum by hypertonic saline does not cause airway inflammation. Am J Respir Crit Care Med 1995; 151: A704. 